\title{
FAIR TRIAL v. FREE PRESS IN CRIMINAL TRIALS
}

A white girl was raped by four Negroes in the state of Florida. Four suspects were soon arrested and local newspapers, reporting that confessions had been obtained, further stirred an already enraged public. On trial, the defendants were sentenced to death, although the purported confessions were never offered by the State. On appeal to the United States Supreme Court, the convictions were reversed per curiam, and Justice Jackson in a concurring opinion said in part, "The verdict was dictated by the press and the public opinion it generated ... one of the best examples of one of the worst menaces to American Justice." 1

This case illustrates one phase of a perplexing problem in American courts today ${ }^{2}$ resultimg from the inevitable conflict of two constitutionally protected rights, fair trial ${ }^{3}$ and free press. ${ }^{4}$ The problem can best be analyzed by a breakdown of frequently arising factual situations within each of the two major divisions and a consideration of the holdings in each area.

\section{FAIR TRIAI}

\section{A. Right to a Public Trial}

The Sixth Amendment to the United States Constitution provides in part that, "In all criminal proceedings the accused shall enjoy the right to a speedy and public trial. ..." And in In re Oliver ${ }^{\mathbf{5}}$ the Suprene Court held that the right to at least the presence of defendant's relatives, friends and counsel is also protected by the due process clause of the fourteenth amendment in state proceedings. In addition, forty-three states have expressly provided for a public trial either by constitution or statute. ${ }^{6}$ The protection derives from historical judicial travesties such as the notorious Star Chamber tactics, the Spanish Inquisition and the French Monarchy's lettre de cachet. It is, however, not an absolute right, and the several state and federal jurisdictions have interpreted it with contradictory results. Contrast, for example, two federal district court holdings, just four years apart, one of which sustained an order dismissing all spectators except relatives of the defendant, attorneys and the press in a minor-rape case, ${ }^{7}$ while the other held a similar order invalid in an adult-rape trial, on the ground that it deprived the defendant of a fair trial. ${ }^{8}$

A. California case ${ }^{9}$ illustrates other typical limitations on the right.

1 Shepard v. Florida, 341 U.S. 50, 55 (1951).

2 The English courts have settled the problem in favor of the accused where there is a question of possible prejudice to him. Rex v. Parke, (1903) 2 K.B. 432 (editor convicted of contempt for publishing derogatory statements before trial); Rex v. The Evening Standard, 40 T.L.R. 833 (K.B. 1924) (contempt upheld for publishing result of newspaper's private investigation of case); Rex v. Davies, (1945) 1 K.B. 435 (editor fined for publishing "facts other than those given in open court" after trial, pending appeal).

3 U.S. Const. amend. V, XIV.

\& U.S. CoNsT. amend. I, XIV.

5333 U.S. 257 (1947) (Michigan's secret one-man grand jury held unconstitutional).

6 See, e.g., CaL. Const. art. I, § 13; Dex. Const. art. I, \& 7; III. Const. art. 2, § 9; Micr. Const. art. 2, § 19; MINN. Const. art. 1, § 6; NEW YoRk Const. art. 2, § 12; Ore. Const. art. $1, \S 11$; WASH. CoNST. art. I, §22.

7 Reagan v. United States, 202 Fed. 488 (9th Cir. 1913).

8 Davis v. United States, 247 Fed. 394 (8th Cir. 1917).

${ }^{9}$ People v. Hartman, 103 Cal. 242, 37 Pac. 153 (1894). 
The trial should be public in the ordinary common sense acceptation of the term. The doors of the court room are expected to be kept open, the public are entitled to be admitted, and the trial is to be public in all respects, as we have before suggested, with due regard to the size of the court room, the conveniences of the court, the right to exclude objectional characters and youth of tender years, and to do other things which may facilitate the proper conduct of the trial.10

The above cited cases apply to partial exclusion of the public generally, as opposed to the press specifically, and it appears that the latter has never been successfully excluded from proceedings in derogation of the accused's right to a public trial. In the recent case of People v. Jelke, ${ }^{11}$ the defendant was accused of compulsory prostitution of women, and the court excluded the press (and public generally) during the presentation of the case for the people by the district attorney, on the ground that the trial had already been overpublicized and that the nature of the testimony demanded privacy in the best interest of public morals. On appeal by the defendant, the reviewing court reversed the conviction, stating that such action violatd the accused's right to a public trial and that "The demands of public morality do not ... justify nullification of the right of public trial, even in cases of an obscene or indecent nature." 12

It has been suggested that the presence of newspaper representatives is the defendant's best assurance of a fair trial and that the aims of justice might be better served by excluding the curiosity seekers and morbid onlookers in favor of a well represented press. ${ }^{13}$ The advantages of a public trial would essentially be retained ${ }^{14}$ while doing away to some extent with overcrowded court rooms with the attendant noise and general confusion, "hamming" by attorneys for both sides, and direct contact by youths with lust-provoking testimony.

10 People v. Hartman, 103 Cal. 242, 245, 37 Pac. 153, 154 (1894). See also, People v. Kerigan, 73 Cal. 222, 14 Pac. 849 (1887) (approval of order excluding all but court officers, reporters and friends of defendant to prevent disorder in court room) ; People v. Byrnes, 84 Cal. App. 2d 72, 190 P.2d 290 (1948) (accord) ; State v. Johnson, 26 Idaho 609, 144 Pac. 784 (1914) (exclusion allowed where public morals demand); People v. Yeager, 113 Mich. 228, 71 N.W. 491 (1897) (accord); State v. Soale, 308 Mo. 573, 274 S.W. 393 (1925) (exclusion approved to limit attendance to seating capacity). But cf. United States v. Kobh, 172 F.2d 919 (3d Cir. 1949).

11308 N.Y. 56, 123 N.E.2d 769 (1954).

12 Citing Tanksley v. United States, 145 F.2d 58 (9th Cir. 1944) (general public excluded during rape victim's testimony contradicting accused's defense that she was a prostitute; conviction reversed); see also, United States v. Kobl, 172 F.2d 919 (3d Cir. 1949) (public excluded from Mann Act prosecution; on appeal conviction reversed, the court saying, "we think that the franker and more realistic attitude of the present day toward matters of sex precludes a determination that all members of the public, the mature and experienced as well as the immature and impressionable, may reasonably be excluded from the trial of a sexual offense upon the ground of public morals").

13 Radin, Right to a Public Trial, 6 TearP. L.Q. 381 (1932), citing with approval, Reagan v. United States, note 7 supra.

14 The advantages nost frequently cited by proponents of public trial are as follows: (1) it produces a disinclination on the part of witnesses to falsely testify (Tanksley v. United States, 145 F.2d 58 (9th Cir. 1944)) ; (2) it brings key witnesses forward to offer or dispute testimony who would not otherwise know of the opportunity (6 WIGMORE, EvDEENCE \&1834 (3d ed. 1940)); (3) it insures best efforts from court officers (State v. Keeler, 52 Mont. 205, 156 Pac. 1080 (1916)); (4) it precludes the revival of Star Chamber tacties and elimimates public fear and distrust of the judicial process (In re Oliver, 333 U.S. 257 (1948)); (5) those in attendance nuay serve as witnesses to the impartiality of a judge under criticisin (1 BENTHAM, RATrONALE OF JUDICIAL EVIDENCE 524 (1827)); (6) those in attendance may report any irregularities prejudicial to, or in favor of, the accused (State v. Osborne, 54 Ore. 289, 103 Pac. 62 (1909)). 


\section{B. Right to an Orderly Trial}

The right to a trial conducted in an atmosphere of calm judicial appraisal is inherent in the constitutional guaranty of a fair trial. Unfortunately this has not always been attained. Consider, for example, the trial of Bruno Richard Hauptman for the kidnap-murder of young Charles A. Lindbergh Jr. in 1932, unquestionably the most publicized and chaotic case of its time. ${ }^{15}$ The unprecedented press coverage (an estimated 700 newspapermen were present during the trial) was anything but conducive to an orderly proceeding.

Crowds surged through the streets of the town, eye witne:ses say, at the rate of 20,000 a day. They jammed the access to the court house, filled its narrow passage ways, and, on one occasion, even shattered the glass in the entrance door. With no thought of promoting the interest of justice they jostled and thronged as though at a circus or holiday event, buying eagerly and freely from norbid vendors, souvenir ladders, a reminder of the ladder which was one of the instruments used in the commission of the foul crime.10

Inflamatory headines attracted crowds and distracted witnesses ${ }^{17}$ while the defendant fought for his life.

Out of the chaos and shame of the trial, in which Hauptman was convicted and sentenced to death ${ }^{18}$ by a remarkably poised jury and judge, came the adoption by the American Bar Association of Canon 35 of the Judicial Code of Ethics. The Canon, which has been adopted either by the bar or as a rule of court in twenty-one states, is extremely strict, prohibiting all photographs, broadcasting and television during court session. Although joining with the Canon's proponents in earnest condemnation of the Hauptman tragedy, the press generally condemns Canon 35 as a severe reaction to a danger now non-existent in the light of modern methods which render photography and television impossible to detect. The basic rationale of the American Bar Association Committee, however, is that, "in most of them (stories, pictures and headlines) the writer is arguing, from the evidence, from supposed facts, to the public as judge and jury. We must not have two trials, one in court and one outside." 19

\section{Right to an Impartial Trial}

This category deals with the problem illustrated in the opening paragraph, where, along with publishing a sensationalistic impression during the trial, the press reports prior to the trial on confessions, prior convictions, charges, and other damaging matters which in fact never existed or for some reason are inadmissable. In the Shepard case $e^{20}$ the conviction attained under such circumstances was reversed, and justifiably so. It appears, however, that this case has been narrowly construed, and in nearly every trial in which the accused has invoked it (typically

15 The Honorable Newton D. Baker, Chairman of the American Bar Association Joint Investigatory Committee in 1936, characterized the trial in his BAKER COMAMTIEE REPORT as "perhaps the most spectacular and depressing example of improper publicity and professional misconduct ever presented to the people of the Umited States in a criminal trial."

16 Hallam, Some Object Lessons on Publicity in Criminal Trials, 24 MnNN. L. REv, 453 (1940).

17 "The Flemington Circus-This Way to the Big Tent"; "Hauptamann Shows Stgns of Cracking"; "Bruno Aimi PIerced"; "Hauptamann's Case Crumables." Id. at 486.

18 Cert. denied, Hautmann v. New Jersey, 296 U.S. 649 (1935). (1940).

19 Report of Special Committee on Publicity in Criminal Trials, 24 MnNr. L. REv. 477

20 See note 1 supra. 
in a plea for change of venue) the court has had little difficulty in distinguishing its immediate case on the facts, affirming the conviction on the ground that wide discretion in such matters lies in the trial court. ${ }^{21}$

An example of California's handling of this situation is presented in People $v$. Stroble. ${ }^{22}$ In this case, a six year old girl was brutally murdered in the home of the accused party's daughter and son-in-law. The accused had four months previously been charged with fondling small girls and had fled the state following release on bail. He had returned to his daughter's hoine in Los Angeles just prior to the murder, and disappeared immediately after the crime was committed. Soon after capture of the accused, the district attorney released details of his alleged statements, including admissions of sex play with the victin, and announced that the defendant was guilty and sane. (The California Supreme Court later found at least the first confession to be "the result of physical abuse or psychological torture or a combination of the two." ${ }^{23}$ ). The result, of course, was "sensational publicity" and "popular hysteria." 24

At the time of defendant's arrest and at the time of his trial (which began some seven weeks later) there was notorious widespread public excitement, sensationally exploited by newspaper, radio and television, concerning crimes against children and defendant's crime in particular. ${ }^{25}$

The California Supreme Court condemned the courtrooin photograplis and television as improper, but affirmed the conviction on the ground that "there is no indication that the jury's verdict was influenced by the taking of the pictures or the televising of the court room scenes. ${ }^{326}$

It would appear that California has resolved the doubt in this area of indirect conflict favorably to the press rather than the accused. By placing the burden of proof upon the defendant to show that "the jury's verdict was influenced," 27 a burden nearly impossible to carry, the court has effectively disregarded the warning of Justice Jackson in the Shepard case and this statement from yet another jurisdiction: "A fair trial means a trial before an impartial judge, an honest jury, and in an atmosphere of judicial calm." 28

\section{FREE PRESS}

\section{A. Right to Report on Pending Non-Jury Trials}

"The freedom of speech and of the press secured by the First Amendment against abridgment by the United States is similarly secured to all persons by the Fourteenth against abridgment by a state."20 The United States Supreme Court has been extremely zealous in enforcing this protection in pending non-jury trials where the press is vociferously demanding conviction or other disposition in accordance with its own views. The trial judge will cite the newspaper for contempt,

21 Mayo v. Blackburn, 250 F.2d 645 (5th Cir. 1957); United States v. Moran, 236 F.2d 361 (2d Cir. 1956) ; Reynolds v. United States, 225 F.2d 123 (5th Cir. 1955); United States v. Malinsky, 20 F.R.D. 301 (1957); but cf. Henslee v. United States, 246 F.2d 190 (5th Cir. 1957).

2236 Cal.2d 615, 226 P.2d 330 (1951).

$23 I d$. at 623,226 P.2d at 335 .

$24 I d$. at 620,226 P.2d at 334 .

25 Ibid.

$28 \mathrm{Ibid.}$.

27 Ibid.

28 State v. Gossett, 117 S.C. 76, 108 S.E. 290, 292 (1921).

29 Schneider v. State, 308 U.S. 147, 160 (1939). 
on the grounds, for example, that "the publications create distrust for the court, willfully withhold and suppress truth, and tend to obstruct the fair and impartial administration of justice in pending cases." 30

The Supreme Court has been reluctant to inpose limitations on even sensationalistic publicity, if no "clear and present danger" is found, ${ }^{81}$ contrary to the English practice which requires only a possibility of unfairness to justify contempt proceedings. ${ }^{32}$ Thus, the right of freedom of the press in this area is apparently held paramount to the right to a fair trial in borderline cases where the danger of a substantive evil is not serious and imminent enough in the judgment of the reviewing court.

\section{B. Right to Attend Trial Over Defendant's Objection}

The previously discussed Jelke case $^{33}$ had an additional important ramification. The United Press claimed that its rights as well as those of the defendant had been violated by the lower court's exclusion of the public on its own motion.

Although the appellate court had already reversed Jelke's conviction on the ground that the exclusion deprived him of his constitutional and statutory ${ }^{34}$ right to a public trial, thus mooting the issue, in United Press $v$. Valente ${ }^{36}$ the court squarely faced it, holding that the right was in defendant alone, subject to his waiver. This was the first case in which the public's right to attend was litigated. Regarding the specific right of the press to be present, the court said that the doctrine of free speech has "never been held to confer upon the press a Constitutionally protected right of access to sources of information not available to others" and it is "in no way abridged by an exclusionary ruling which denies to the public generally, including newspapermen, the opportunity to see and hear what transpired." 36

United Press claimed also under a statute which read in part, "The sittings of every court within this state shall be public. and every citizen may freely attend the same." ${ }^{87}$ The court resisted the argument, stating; that the right was in the public generally, and not one on which an individual could insist. ${ }^{88}$ The court further reasoned that "To deny the right of waiver in such a situation would be 'to convert a privilege into an imperative requirement' to the disadvantage of the accused," 39 and that,

30 Pennekamp v. Florida, 328 U.S. 331 (1946).

31 Bridges v. California, 314 U.S. 252 (1941). In this case, the California courts had held a newspaper publisher in contempt for its conduct in publishing views concerning cases not yet finally determined, which allegedly tended to interfere with the fair and orderly administration of justice. The Supreme Court reversed, saying that to derogate from the constitutional guaranty of free press the publication must indicate a "clear and present danger" (defined in Schenk v. United States, 249 U.S. 47, 52 (1919)) wbich points to a substantive evil which must itsclf be "substantial." (See Whitney v. California, 274 U.S. 35", 374 (1927)). The Court concludes at page 263 , "What finally emerges from the 'clear and present danger' cases is a working principle that the substantive evil must be extremely serious and the degree of imminence extremely high before utterances can be punished." (Empbasis added.) Accord, Craig v. Harney, 331 U.S. 367 (1947) ; Pennekemp v. Florida, 328 U.S. 331 (1946).

32 See note 2 supra.

${ }^{33}$ See note 11 supra.

${ }^{34}$ N.Y. Cons. Laws., Vol. 29, Judiciary Law \$ 4.

85308 N.Y. 71, 123 N.E.2d 777 (1954).

36 Id. at 778.

37 See note 34 supra.

38308 N.Y. 71, 85, 123 N.E.2d 777, 783 (1954).

39 Id. at 82,123 N.E. $2 \mathrm{~d}$ at 781 , citing United States v. Sorrentino, 175 F.2d 721, 723 (3d Cir. 1949). 
While publicity ordinarily serves to assure a fair trial, the defendant may determine reasonably and sensibly that he will be able to secure such a trial only by limitation of the number of spectators-where, e.g., a particular crime has aroused intense feeling in the community. Cf. Moore v. Dempsey, 261 U.S. 86.40

The court also warned that an overwhelming number of collateral proceedings could result if parties denied access could nivoke the statute and stay the main trial while their asserted rights are being finally determined.

An opposite result was reached in the Ohio case of Scripps v. Fulton.11 There, a defendant in a pandering case clainied that a cross examination of a prosecuting witness in private would more effectively get to the truth. Scripps, a publisher, brought this action seeking a writ prohibiting the trial judge from excluding the public during the testimony of the witness. In a holding irreconcilable with the Valente case, the court allowed the writ stating in part,

In Section 10, Art 1,42 it is provided that a defendant is entitled to a public trial. This constitutional provision is one for the benefit of the defendant. It does not, however, guarantee the defendant to a private trial as against the public whose interests are equally involved in the judicious administration of the law. 43 (emphasis added.)

The court rather incongruously provides for the exclusion, in nuorals offense cases, of "those who by reason of imnaturity or otherwise, would be harmfully affected in attending such a proceeding," ${ }^{34}$ then in the very next paragraph gives a free license to the press to print what they wish: "The public morals are not protected by trying to hide its sins behind closed doors. Better that we know our faults that we may ever increase our efforts to live in social rectitude." $4 \mathrm{~b}$

One might ask whether the excluded youth night not find nore than adequate solace in discovering that the details of the particular moral offense have been perpetuated in print by the local newspaper for his less inhibited study.

The recent case of Kirstowsky v. Superior Court ${ }^{46}$ indicates what unight be considered the California compromise to the problem. At the start of defendant's murder trial, she waived her right to public proceedings in order to reveal in her testimony a number of abnormal sex practices suffered by her at the hands of the victim. She claimed that in her present state of emotional disturbance it would be impossible to present the testinony in a public hearing. The court thereupon excluded the public and press from the trial. On application for a writ of mandate by several newspaper publishers the district court of appeal held that the trial court "went too far" in excluding the public throughout the entire trial. Although conceding that defendant's right to a fair trial is paramount to the statutory right of the public to attend such trial, ${ }^{47}$ the holding apparently places the burden upon the defendant to prove that testimony should be excepted from the general statutory rule. The court of appeal held that only the defendant's specific testimony fell within the exception.

It is submitted that the compromise, though better reasoned than the Scripps

$40 I d$. at 82,123 N.E.2d at 781 .

41100 Ohio App. 157, 125 N.E.2d 896, appeal dismissed, 164 Ohio 261, 130 N.E.2d 701 (1955).

${ }^{42}$ Onro Const. California has a similar provision, Cax. Const. art. I, § 13.

43100 Ohio App. 157, 161, 125 N.E.2d 896, 899 (1955).

44 Id. at 169,125 N.E.2d at 904.

45 Ibid.

46143 Cal. App. 2d 745, 300 P.2d 163 (1956).

47 CaI. CODE Crv. Proc. 124: "The sittings of every court of justice shall be public . ..." 
case, is vulnerable to at least three criticisms. First,it assumes somewhat unrealistically that a group of experienced newspapermen can be excluded from the court room for, say, fifteen minutes, and will not on their return find out in some manner substantially what was said. Secondly, assuming this criticism unfounded, there is the danger of the public receiving a distorted view of the trial because of having access to only fragments of it. Third, a more philosophical than legalistic criticism: is a compromise ever justified when a man's life is at stake in a society which presumes a man innocent until proven guilty?

\section{CoNCLUSTON}

No one would argue that it is not "the right and duty of the court to see that the parties are granted a fair and impartial trial." 48 Anything less is a denial of due process of law." The dispute arises in the meaning of "fair and inpartial trial," for the term defies a universal definition.

Every thinking free man is aware of the danger imminent in even the slightest encroachment on the right of free expression of any kind. But an equally dominating consideration in a democracy is the high value attached to the human life, manifested in a system of law which, as mentioned before, presumes a man innocent until proven guilty, all evidence to the contrary notwithstanding. We are in an era of unprecedented lawlessness and inter-racial tension. Improved methods of communication can now knit a large city together as never before possible. Flames of public sentiment can be quickly fanned white lot, especially now with the ubiquitous television set bringing all the court room emotion into the family living room, and there is no doubt, in California at least, that "the protection given to the freedom of speech and press is extended to the medium of television, there being no distinction between the various methods of communication." ${ }^{50}$ Canon 35 of the Judicial Code of Ethics, which has been adopted as a rule of court in nine states and by bar associations in twelve others, ${ }^{b 1}$ was amended in 1952 to include television within its restrictive language. The canon now reads in part,

Proceedings in court should be conducted with fitting dignity and decorum. The taking of photographs in the court room, during sessions of the court or recesses between sessions, and the broadcasting or televising of court proceedings are calculated to distract from the essential dignity of the proceedings, distract the witness in giving his testimony, degrade the court, and create misconceptions with respect thereto in the mind of the public and should not be permitted, 52

Judicial Ethics Canon 35, along with the impotent Professional Ethics Canon 20 , which proscribes pre-trial publication by lawyers, ${ }^{13}$ las been the subject of

4888 C.J.S. Trial $\$ 36$ (1955).

49 Powell v. Alabama, 287 U.S. 45 (1932).

50 Wrather-Alvarez Broadcasting, Inc. v. Hewicker, 147 Cal. App. 2d 509, 512, 305 P.2d 236, 238 (1957). (The court cites Kirstowsky v. Superior Court, 143 Cal. App. 2d 745, 300 P.2d 163 (1956), for the proposition that the public as well as the accused has the right to a public trial under CAX. CODE CIV. Proc. \& 124.)

5119 F.R.D. 16, 22 (1957).

52 A.B.A. Canons of Professional and Judicial Ethics, Canon 35 (1957) p. 57.

53 Canon 20 states in part, "Newspaper publications by a lawyer as to pending or anticipated litigation may interfere with a fair trial in the courts and otherwise prejudice the adininistration of justice. Generally they are to be condemned." 
much criticism by both press and bar. It is submitted, however, that before condemning it, several factors must be considered.

(1) Gentlemanly co-operation between press and bar, though desirable and advocated by both parties and members of the bench as well, ${ }^{54}$ has proven to be an unrealistic solution to the problem with little hope of complete success.

(2) It is practically impossible to prevent jurors from reading newspapers, and even the cumbersome and costly jury lock-up is not foolproof. ${ }^{55}$

(3) Jurisdictions which allow wide discretion to the trial court are assuming that the judge will be able to determine whether or not a trial not yet begun will be rendered unfair by allowing it to be televised. The problems are readily apparent. For example, only with a prohibitive pre-trial psychological study of all jurors and witnesses could it be determined that each will discharge his duty in the best interest of justice knowing that his every movement and word will be observed by thousands of viewers. Not even experienced counsel can be depended upon not to under or overplay their roles under the pressure of mass audiences.

(4) A judge cannot insure that a witness is going to confine lis testimony to the wholesome standard suitable for television's youthful and unexcludable audience.

In the light of the decisions just reviewed wlicli vest in the press an absolute, ${ }^{58}$ or at least a qualified ${ }^{57}$ right to attend and report on the trial of a non-assenting defendant, both Canons 35 and 20 sliould be adopted as rules of court, enforceable by contempt preceedings. Our system of justice demands that in an area frauglit with doubts, such doubts be resolved in favor of the accused as long as they persist.

John S. Martel*

04 19 F.R.D. 16 (1956); 63 A.B.A. ReP. 384 (1938); New York Times, Aug. 26, 1953; Dallas Morning News, Aug. 25, 1953.

55 62 A.B.A. REP. 858 (1937); 40 A.B.A.J. 838 (1954).

68 Scripps v. Fulton, 100 Ohio App. 157, 125 N.E.2d 896, appeal dismissed, 164 Ohio 261, 130 N.E.2d 701 (1955).

o7 Kirstowsky v. Superior Court, 143 Cal. App. 2d 745, 300 P.2d 163 (1956).

* Member, Third-Year Class. 